\title{
1
}

\section{Measurement of Ligand-G Protein-coupled Receptor Interactions}

\author{
Katie Leach, Celine Valant, Patrick M. Sexton and Arthur Christopoulos
}

Drug Discovery Biology Laboratory, Monash Institute of Pharmaceutical Sciences and Department of Pharmacology, Monash University, Parkville, 3052, Australia

\subsection{Introduction}

\subsubsection{Ligand-receptor interactions and the law of mass action}

Radioligand binding assays take advantage of the ability to detect the decay of radioactive material, which can be incorporated into a ligand of choice. The interaction of such a radioligand with a receptor preparation can subsequently be determined by capturing and measuring the amount of radioactivity present. Radioligand binding assays can be used to estimate molecular parameters, such as the density of receptors present in a tissue or cellular preparation or the affinity of a ligand for binding to a receptor.

The simplest scheme that describes the binding of a ligand to its receptor is based on the law of mass action:

$$
\mathrm{A}+\mathrm{R} \underset{K_{\text {off }}}{\stackrel{K_{\text {on }}}{\longrightarrow}} \mathrm{AR}
$$

where the ligand $\mathrm{A}$ binds to the receptor $\mathrm{R}$ to form the ligand-receptor complex AR. The rate at which the ligand binds to the receptor, expressed as the number of binding events per unit of time, is dependent on the ligand concentration, the number of

G Protein Coupled Receptors Edited by David R. Poyner and Mark Wheatley (C) 2010 John Wiley \& Sons, Ltd. 
unoccupied receptors and the association rate constant $K_{\text {on }}$. In contrast to an enzymatic reaction, there is no degradation of the product $\mathrm{AR}$; and if this reaction is reversible, then the ligand-receptor complexes can dissociate into free receptor and ligand, which is dependent on the concentration of ligand-receptor complexes and the dissociation

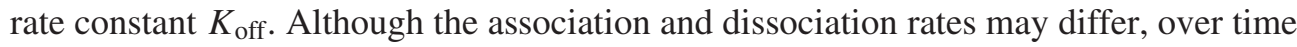
an equilibrium state will arise whereby the rate at which new ligand-receptor complexes are formed will equal the rate at which ligand-receptor complexes break down. At equilibrium, the ratio of the dissociation and association rate constants provides a useful measure of the overall strength with which a ligand interacts with a receptor, the equilibrium dissociation constant $K_{\mathrm{a}}$ (although sometimes referred to as $K_{\mathrm{d}}$ ) and expressed in moles per litre. $K_{\mathrm{a}}$ is also the concentration of ligand that binds half the receptors present. Therefore, at equilibrium, the concentration of ligand-receptor complexes is governed by the total receptor density $\left[\mathrm{R}_{\mathrm{T}}\right]$, the ligand concentration $[\mathrm{A}]$ and the equilibrium dissociation constant of the ligand:

$$
[\mathrm{AR}]=\frac{\left[\mathrm{R}_{\mathrm{T}}\right] \times[\mathrm{A}]}{[\mathrm{A}]+K_{\mathrm{a}}}
$$

where $\left[\mathrm{R}_{\mathrm{T}}\right]=[\mathrm{R}]+[\mathrm{AR}]$ and $K_{\mathrm{a}}=K_{\mathrm{off}} / K_{\mathrm{on}}$.

Equation 1.1 is often referred to as the Hill-Langmuir binding isotherm and describes equilibrium binding of a ligand to a receptor under the law of mass action, such that a hyperbolic curve will result when binding is plotted against the molar ligand concentration. This was first used by A.V. Hill to describe the binding of oxygen to haemoglobin [1,2]. If ligand concentrations are expressed in logarithmic space, then a sigmoidal concentration-occupancy curve will be apparent. If binding of a ligand to a receptor at equilibrium follows a simple mechanism, where the binding of one ligand molecule is unaffected by concomitant binding events and where the ligand binds to only a single class of receptor sites, then the concentration-occupancy relationship plotted on a logarithmic scale will follow a sigmoidal curve that approximately spans from 10 to $90 \%$ occupancy over a 100-fold, or two log-unit, concentration range. The steepness of the slope of such a curve in linear space, the Hill coefficient, will equal unity.

\subsubsection{Competitive interactions at $\mathrm{G}$ protein-coupled receptors}

\subsubsection{Antagonist binding}

Although ligand-G protein-coupled receptor (GPCR) interactions can be quantified by observing the binding of a radiolabelled ligand to a receptor, it is sometimes more practical to measure the ability of a fixed concentration of radioligand to bind to the receptor in the presence of increasing concentrations of an unlabelled ligand, to indirectly determine the interaction of the unlabelled ligand with the receptor. If we consider the binding of ligand $\mathrm{A}$ in the presence of a competitor $\mathrm{B}$ at equilibrium:

$$
\mathrm{A}+\mathrm{BR} \underset{K_{\text {off }}}{\stackrel{K_{\text {on B }}}{\rightleftarrows}} \mathrm{A}+\mathrm{R}+\mathrm{B} \underset{K_{\text {off A }}}{\stackrel{K_{\text {on A }}}{\leftrightarrows}} \mathrm{AR}+\mathrm{B}
$$


then we can define the concentration of receptors bound to the radiolabelled ligand $\mathrm{A}$ in the presence of an unlabelled competitive ligand B, which was first derived by Gaddum [3, 4]. A form of this relationship can be described by

$$
[\mathrm{AR}]=\frac{\left[\mathrm{R}_{\mathrm{T}}\right] \times[\mathrm{A}]}{[\mathrm{A}]+K_{\mathrm{a}}\left(1+\frac{[\mathrm{B}]}{K_{\mathrm{b}}}\right)}
$$

Competitive binding data are commonly expressed as the fractional inhibition of radioligand binding in the presence of the competitor. However, the binding of some ligands does not follow the simple law of mass action and receptor occupancy is not always directly proportional to ligand concentration (see Section 1.1.2.2). Under these circumstances, the Hill slope may vary from unity and must, therefore, be empirically incorporated into any ligand binding equation to derive the steepness of the slope describing the concentration-occupancy relationship, as shown in Equation 1.3:

$$
Y=\frac{\text { Top }- \text { Bottom }}{1+\frac{[\mathrm{B}]^{n}}{\mathrm{IC}_{50}}}+\text { Bottom }
$$

where $Y$ is radioligand binding, Top is the top asymptote of the curve equal to total binding of the radioligand in the absence of competitor B, Bottom is the bottom asymptote of the curve equal to nonspecific binding, $n$ is the Hill coefficient and $\mathrm{IC}_{50}$ is the concentration of $\mathrm{B}$ that inhibits $50 \%$ of radioligand binding. If the Hill coefficient equals unity, then the equilibrium dissociation constant of the unlabelled ligand $K_{\mathrm{b}}$ can be determined using the Cheng-Prusoff equation [5]:

$$
K_{\mathrm{b}}=\frac{\mathrm{IC}_{50}}{1+\frac{[\mathrm{A}]}{K_{\mathrm{a}}}}
$$

\subsubsection{Agonist binding}

Although binding of an antagonist to a receptor will often display a concentrationoccupancy relationship that has a Hill coefficient of unity, agonist binding to GPCRs is usually more complex. This has been well characterized in competition assays between agonists and radiolabelled antagonists, which often yield shallow curves, with Hill coefficients less than unity. These shallow curves reflect different receptor states, for which the agonist has different affinities and the (often) biphasic nature of the curves gives rise to a competition curve that spans greater than a twofold concentration range of competitor (see Figure 1.1).

The addition of guanine nucleotides such as guanosine diphosphate, guanosine triphosphate (GTP), guanylylimidodiphosphate (GppNHp) and guanosine $5^{\prime}$-O (3-thiotriphosphate) $(\mathrm{GTP} \gamma \mathrm{S})$ often alters the proportion and affinity of the two binding sites, demonstrating that the dispersion of agonist affinity states reflects the formation of a ternary complex consisting of an agonist, a GPCR and a guanine 


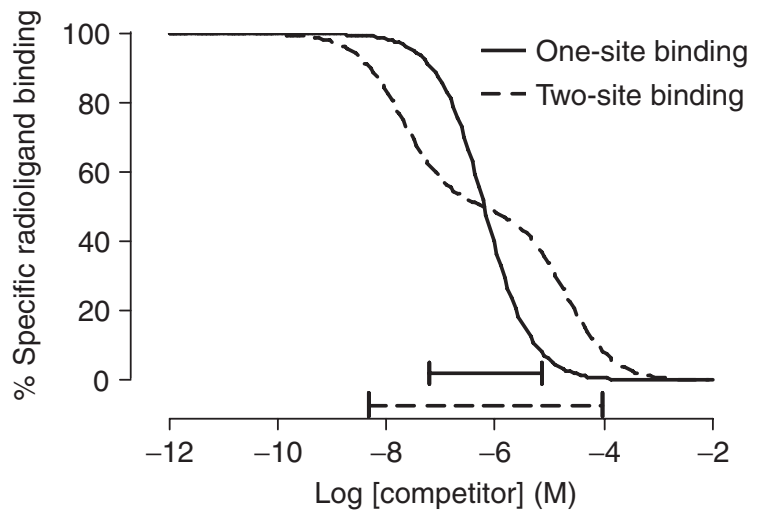

Figure 1.1 Theoretical competition binding curve simulated using a one-site binding fit that follows a Hill slope of unity (solid line) in comparison with a two-site binding fit that follows a shallow slope (dashed line).

nucleotide binding protein (G protein). A ternary complex model (TCM) has been proposed to explain the shallow curves observed with agonists versus radiolabelled antagonists in competition binding assays, but requires a number of assumptions that are not often met [6]. For instance, it must be assumed that the $\mathrm{G}$ protein is limiting so that not all of the receptors can form a complex with the $G$ protein, enabling both $\mathrm{G}$ protein-coupled (high-affinity) and -uncoupled (low-affinity) receptor species to be observed. This is rarely observed in cellular systems used to study many ligand-GPCR interactions, where G protein levels often exceed those of receptor expression levels.

More sophisticated extensions of the TCM have been developed to account for the ability of agonists to bind with higher affinity to receptors that have been mutated to exert constitutive activity than to their wild-type counterparts, even in the absence of $\mathrm{G}$ proteins [7]. However, in general there is little advantage to using the extended TCM for routine data analysis, as the simpler TCM can adequately approximate the binding of agonists to a receptor.

\subsubsection{Allosteric ligands}

For a number of GPCRs, there are ligands that can bind to the receptor at a site that is topographically distinct from the endogenous, or orthosteric, ligand binding site [8]. These binding sites and the ligands that bind to them are referred to as 'allosteric'. Since allosteric ligands do not directly compete for binding with the orthosteric ligand, they have the ability to form a ternary complex in which both the orthosteric and the allosteric ligand occupy the receptor (see Figure 1.2).

Binding of an allosteric ligand to a receptor may alter the receptor conformation such that binding of the orthosteric ligand is altered, and vice versa. These changes in binding are termed 'cooperative effects' [9].

In terms of binding, the allosteric TCM predicts that an allosteric modulator may inhibit $(0<\alpha<1)$, enhance $(\alpha>1)$ or have no effect $(\alpha=1)$ on the binding of an 


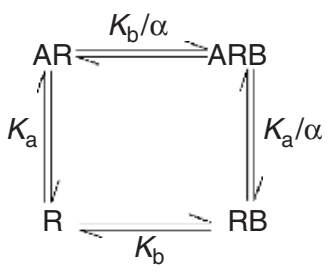

Figure 1.2 A ternary complex model describing the binding of an orthosteric ligand $A$ and an allosteric modulator $\mathrm{B}$ to a receptor $\mathrm{R} . K_{\mathrm{a}}$ and $K_{\mathrm{b}}$ are the equilibrium dissociation constants of $\mathrm{R}$ for $A$ and $B$ respectively, $\alpha$ is the binding cooperativity between $A$ and $B$ (the selectivity of $A$ for $R$ and $R B$ or of $B$ for $R$ and $A R$ ) and, therefore, determines the effect of $B$ on the binding of $A$ and vice versa.

orthosteric ligand. The formation of a ternary complex between the receptor, the orthosteric ligand and the allosteric modulator can be described by

$$
[\mathrm{AR}]+[\mathrm{ARB}]=\frac{\left[\mathrm{R}_{\mathrm{T}}\right] \times[\mathrm{A}]}{[\mathrm{A}]+K_{\mathrm{a}}\left[\left(1+\frac{[\mathrm{B}]}{K_{\mathrm{b}}}\right) /\left(1+\frac{\alpha[\mathrm{B}]}{K_{\mathrm{b}}}\right)\right]}
$$

Several recent reviews provide detailed information regarding our understanding of such compounds and the methods that can be used to detect and analyse allosteric interactions $[8,10,11]$.

\subsection{Methods and approaches}

\subsubsection{General considerations for radioligand binding assays}

\subsubsection{Buffers}

Acidic, basic or neutral buffers, consisting of $\mathrm{pH}$ buffering agents such as trishydroxymethylaminomethane hydrochloride (tris acid), trishydroxymethylaminomethane (tris base) and 4-(2-hydroxyethyl)-1-piperazine-ethanesulfonic acid (HEPES), are all commonly used for radioligand binding assays, usually at concentrations of $10-50 \mathrm{~mm}$. HEPES-based buffers are popular as HEPES is relatively heat stable. For some receptors, ligand binding and receptor activity are highly dependent upon $\mathrm{pH}$, particularly as both the receptor and the ligand may be protonated (acidified) or deprotonated depending on the $\mathrm{pH}$. Many researchers chose to perform radioligand binding assays at $\mathrm{pH} 7.4$, which resembles a physiological environment.

The composition of the buffer is particularly important, as certain trace metals can directly interact with GPCRs and alter their behaviour. For instance, $100 \mathrm{~mm}$ $\mathrm{NaCl}$ is commonly used to maintain a high ionic strength, yet sodium can destabilize receptor $-\mathrm{G}$ protein formation by interacting with a highly conserved aspartate residue in transmembrane domain 2 of Family A GPCRs [12], which can have implications for the binding of agonists and inverse agonists. Sodium may also have less specific effects that are due to the ionic strength of the buffer, and comparing the effects of sodium 
and potassium may be useful to determine the potential impact of this phenomenon. Alternatively, $100 \mathrm{~mm} N$-methyl-D-glucamine may be substituted for sodium to alter ionic strength whilst having no effects on receptor $-\mathrm{G}$ protein coupling. Additional ions may also have direct effects on ligand binding or receptor activity. For instance, magnesium is required for efficient coupling between the receptor and $\mathrm{G}$ protein and may, therefore, enhance the proportion of high-affinity agonist binding sites. Magnesium is usually present in the buffer at concentrations between 1 and $10 \mathrm{~mm}$, a concentration that can also be used in functional membrane-based assays such as $\left[{ }^{35} \mathrm{~S}\right] \mathrm{GTP} \gamma \mathrm{S}$ binding assays. Calcium can directly bind to members of the Family C GPCRs to alter the binding of ligands [13] and can also activate certain proteases that may enhance degradation of the receptor. Ethyleneglycoltetraacetate (EGTA) may be added to the assay buffer to chelate calcium ions and act as a protease inhibitor, whilst ethylenediaminetetraacetate (EDTA) is useful for chelating additional trace metals, such as magnesium, to prevent ligand oxidation. For these reasons, EDTA is a useful component in the buffer used to prepare membranes for radioligand binding (see Section 1.2.2.1). Additional protease inhibitors may also be added, such as serine-, cysteine- and metallo-protease inhibitors.

Finally, the buffer must also be optimal for the ligands to be used in the radioligand binding assay. Some ligands, particularly 5-hydroxytryptamine and catecholamines such as dopamine, epinephrine and norepinephrine, are particularly susceptible to oxidation, so an antioxidant such as ascorbic acid can be added to the buffer to prevent this. Other ligands, such as proteins and peptides, may stick to plastic and glass, and a protein such as bovine serum albumin $(0.001-0.1 \%)$ may be required to coat these surfaces to reduce adsorption of the ligand.

\subsubsection{Temperature and incubation time}

Radioligand binding assays are usually performed at $20-37^{\circ} \mathrm{C}$. Although $37^{\circ} \mathrm{C}$ is physiologically relevant, receptors studied in membrane systems may become unstable at high temperatures. If lower temperatures are used, then care must be taken to ensure that equilibrium binding is reached. Therefore, the temperature at which the experiment is performed depends upon the stability of the receptor and ligands and the binding kinetics of the ligand. The law of thermodynamics predicts that equilibrium will be reached faster at higher temperatures, with an approximate doubling in the reaction rate with a $10^{\circ} \mathrm{C}$ increase in temperature.

With regard to incubation time, this may vary between receptors. The binding of a fixed concentration of radioligand should initially be measured at different time points to determine when equilibrium is attained (see Section 1.2.2.5). The rate at which the ligand-receptor interaction approaches equilibrium is often termed the $K_{\text {observed }}$ or $K_{\mathrm{obs}}$, measured in units of inverse time. $K_{\mathrm{obs}}$ is dependent on the association and dissociation rate constants of the ligand and the ligand concentration, with lower ligand concentrations taking longer to reach equilibrium. Thus, binding of a radioligand to a receptor starting from time point 0 will follow

$$
Y=[\mathrm{AR}]_{\mathrm{Eq}} \times\left(1-\mathrm{e}^{-K_{\mathrm{obs}} t}\right)
$$


where $K_{\mathrm{obs}}=K_{\mathrm{on}}[\mathrm{A}]+K_{\mathrm{off}}$ and $[\mathrm{AR}]_{\mathrm{Eq}}$ is binding once equilibrium has been reached (expressed in units of the $Y$ axis, such as disintegrations per minute (dpm)).

Low ligand concentrations should, therefore, be used when testing equilibration time. It is recommended that five times the dissociation half-life of any ligand should be allowed in order to reach approximately $97 \%$ equilibrium binding with the receptor, which is considered to be sufficient.

\subsubsection{Ligand depletion}

Under ideal experimental conditions only a small fraction of the total ligand added will bind to the receptor or to nonspecific sites. Thus, the free-ligand concentration throughout the assay is generally close to the total concentration of ligand added to the assay. However, if a large proportion of the ligand added is bound, either specifically or nonspecifically, then the concentration of free ligand in solution will deviate significantly from the concentration added to the assay. Generally, if less than $10 \%$ of the ligand is bound at each given ligand concentration, then ligand depletion is minimal and, therefore, is not a concern. Initial experiments can be carried out to optimize the protein content of the assay and ensure that excess radioligand does not bind to the protein added. This can be achieved by measuring the binding of a fixed radioligand concentration in the presence of different concentrations of the receptor preparation and calculating the percentage of radioligand bound at each receptor concentration. If ligand depletion does appear to be a problem, then the assay format may be altered to overcome this. The assay volume may be increased, but a greater amount of ligand will also be required to obtain the same concentration whilst receptor numbers will remain constant. Alternatively, the free radioligand can be measured in each tube if a centrifugation assay is employed (see Section 1.2.1.4). Otherwise, analysis techniques that account for the differences between the added and free ligand concentration can be used (see Section 1.2.2.2).

\subsubsection{Separation of bound from free radioligand}

In order to measure the amount of radioligand bound to the receptor preparation, bound radioligand must usually be separated from free radioligand. The most common separation method is vacuum filtration, whereby the samples are rapidly filtered, generally onto glass-fibre filter paper, and washed to remove radioligand that is weakly bound to the filter or to the receptor preparation. Be aware that high concentrations of membrane can clog the filter pores, leading to slower filtration and washing rates. The wash buffer should be ice-cold and washing should be rapid so as to minimize dissociation of the radioligand from the receptors. Filtration of samples can, however, lead to loss of receptors, as some can pass through the glass-fibre filters. High-speed centrifugation assays may be used to minimize loss of receptor and ensure that a greater proportion of the ligand-bound receptor is collected. However, these assays may require more protein in order to pellet the membrane efficiently. The supernatant can then be removed and the pellet rapidly washed. Centrifugation assays are also useful when ligand depletion is a problem, as the free radioligand concentration can be determined following termination of the assay. 


\subsubsection{General assay protocols}

\subsubsection{Membrane preparations}

Radioligand binding may be studied in a cell line or tissue that endogenously expresses the receptor of interest, or a recombinant cell system in which receptor expression is induced. These assays may be performed on whole cells, on tissues or on soluble and purified receptors. However, a common approach is to prepare membrane preparations from the cell lines or tissues expressing the receptor (Protocol 1.1). Although the generation of membranes can be more expensive than using live cells, the use of membrane preparations is particularly convenient because the membranes can be frozen and stored for several months and defrosted when required. It is recommended to perform each repeat of a radioligand binding assay on a new membrane preparation made from a new tissue preparation or cell passage number.

\section{PROTOCOL 1.1 Preparation of Membranes from Adherent Mammalian Cells}

\section{Equipment and Reagents}

- Lifting buffer; for example, $2 \mathrm{~mm}$ EDTA in a phosphate-buffered saline (PBS) solution ( $150 \mathrm{~mm} \mathrm{NaCl}, 16 \mathrm{~mm} \mathrm{Na}_{2} \mathrm{HPO}_{4}, 4 \mathrm{~mm} \mathrm{NaH} \mathrm{PO}_{4}$ ) for Chinese hamster ovary (CHO) cells, or PBS alone for less adherent cell lines, such as HEK 293 cells

- HEPES-based buffer; for example, 20 mm HEPES, 10 mм EDTA, pH 7.4

- Low-EDTA HEPES-based buffer; for example, 20 mм HEPES, 0.1-1 mм EDTA, pH 7.4

- Low- and high-speed chilled centrifuges

- Homogenizer.

\section{Method}

1 Grow cells to $80-90 \%$ confluence in T175 flasks $\left(175 \mathrm{~cm}^{2}\right)$. Generally, one T175 flask will provide sufficient membrane for approximately 50 assay tubes using $15 \mu \mathrm{g}$ of protein per tube. Remove media and add $10 \mathrm{ml}$ warm lifting buffer ${ }^{a}$ to each flask. For cell lines that are particularly adherent, an initial wash with calcium-free PBS may be required to remove any remaining media. For cell lines that require lifting buffer containing EDTA, incubate for $2-5 \mathrm{~min}$ at $37^{\circ} \mathrm{C}$. Gently tap the flasks to detach cells and collect the cell suspension in appropriate tubes. Wash each flask with $10 \mathrm{~mL} \mathrm{PBS}$ and collect the wash.

2 Centrifuge the cell suspension at approximately $200 \mathrm{~g}$ (approximately $1200 \mathrm{rpm}$ in most bench-top centrifuges) for $10 \mathrm{~min}$ and resuspend the cell pellet in 2-3 mL HEPES- or tris-based buffer ${ }^{b}$ per T175 flask, or an appropriate volume to ensure efficient homogenization (step 3).

3 All subsequent steps should be performed at $4{ }^{\circ} \mathrm{C}$ to reduce activation of proteases. Homogenize the cell solution using a homogenizer. Perform three $5-10 \mathrm{~s}$ bursts at top speed ( $20000 \mathrm{rpm})$ with cooling on ice in between each burst. 
4 Centrifuge the resulting cell lysate at $600 \mathrm{~g}$ (approximately $1700 \mathrm{rpm}$ in most bench-top centrifuges) for $10 \mathrm{~min}$ to separate the nuclear fraction and additional cell debris. If a large pellet is obtained, resuspend the pellet and repeat steps 3 and 4, combining the supernatant obtained following each centrifugation step.

5 Transfer the remaining suspension to new tubes and centrifuge at approximately $40000 \mathrm{~g}$ or higher for $1 \mathrm{~h}$. Resuspend the resulting protein pellet in a HEPES- or tris-based buffer, ${ }^{c}$ which can be the buffer that will be used for subsequent radioligand binding assays, or a predominantly HEPES or tris-based buffer with a low concentration $(0.1-1 \mathrm{~mm})$ of a chelating agent such as EDTA or EGTA. Resuspend in approximately $0.5-2 \mathrm{ml}$ buffer per T175 flask, depending on the expression level of the receptor and subsequently the amount of protein required for each assay.

6 Homogenize the membrane suspension briefly and dispense into aliquots of a suitable volume. Membranes can be stored at $-80^{\circ} \mathrm{C}$, generally for up to 12 months, and the protein content of the preparation can be determined using an appropriate method such as that of Lowry [14] or Bradford [15].

\section{Notes}

${ }^{a}$ It is not recommended to use trypsin for harvesting cells, as receptors may be hydrolysed.

${ }^{b}$ The HEPES- or tris-based buffer should contain 1-10 mM EDTA, EGTA or both to reduce proteolysis of the receptor of interest following homogenization steps.

'Ten confluent T175 flasks should generate approximately $10 \mathrm{ml}$ of protein at a concentration of $1-2 \mathrm{mg} / \mathrm{ml}$.

\subsubsection{Saturation binding assays}

Saturation binding assays are used to determine the binding of different radioligand concentrations to a receptor at equilibrium directly. These assays can be used to derive direct measurements of the total receptor number or density present in the system under investigation and to determine the affinity of the radioligand for the receptor. However, the radioligand will not only bind specifically to the receptor of interest, but will also bind to additional sites within a membrane or cell preparation or to the tubes used to perform the radioligand binding assay. Therefore, nonspecific binding must be determined in parallel using a high concentration of a competing ligand to displace each radioligand concentration from the receptor. Where possible, the competitive ligand used to define nonspecific binding should not be an unlabelled form of the radioligand, as both compounds will compete for the same nonspecific binding sites. Ideally, at least 100-1000 times the $K_{\mathrm{a}}$ of the competitive ligand used to define nonspecific binding should be used to ensure full receptor occupancy.

Protocols 1.2-1.6 for radioligand binding assays describe assays performed in $0.5-1 \mathrm{ml}$ volumes, but are applicable to smaller volume assays that can be scaled down.

Traditionally, specific binding is determined by subtracting nonspecific binding from total binding and the data are analysed using Equation 1.7 (see Figure 1.3). However, 


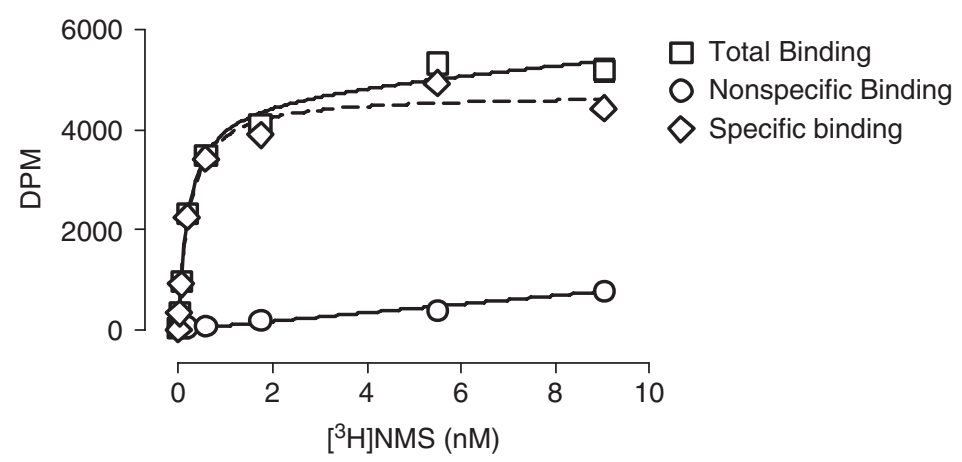

Figure 1.3 Saturation radioligand binding. Binding of the radioligand, $\left[{ }^{3} \mathrm{H}\right] \mathrm{N}$-methylscopolamine $\left(\left[{ }^{3} \mathrm{H}\right] \mathrm{NMS}\right)$, to the $\mathrm{M}_{4}$ muscarinic acetylcholine $(\mathrm{ACh})$ receptor stably expressed in $\mathrm{FlpIn} \mathrm{In}^{\mathrm{TM}}$ $\mathrm{CHO}$ cells, where nonspecific binding was determined in the presence of $10 \mu \mathrm{M}$ atropine. Membranes were incubated with $\left[{ }^{3} \mathrm{H}\right] \mathrm{NMS}$ for $1 \mathrm{~h}$ at $37^{\circ} \mathrm{C}$ before the assay was terminated as described in the methods section.

with the development of more sophisticated computer software, it is now possible to fit the data globally to a model of receptor and nonspecific site occupancy, shown in Equation 1.8. If data are fitted globally, then this means that a family of curves is fitted to a particular model, rather than just a single curve. Parameters common to both datasets can be shared between them, enabling their determination from the relationship between all curves (a comprehensive explanation of global fitting is provided in [16]).

The radioligand-receptor complex concentration [AR] that forms at equilibrium at each radioligand concentration is reflected by the specific binding of the radioligand, expressed on the $y$-axis. We usually call the total number of receptors that are defined by our radioligand as the $B_{\max }$, so specific binding of each radioligand concentration in a saturation binding assay is defined by the Hill-Langmuir occupancy equation using the terms shown in Equation 1.7. Note the relationship to Equation 1.1.

$$
Y=\frac{B_{\max } \times[\mathrm{A}]}{[\mathrm{A}]+K_{\mathrm{a}}}
$$

Nonspecific binding is generally linearly proportional to the radioligand concentration and, therefore, is described by the equation for a straight line. As the total binding TB measured in the experiments represents both specific and nonspecific binding, radioligand binding, expressed on the $y$-axis, to one class of binding sites is defined by

$$
\mathrm{TB}=\frac{B_{\max } \times[\mathrm{A}]}{[\mathrm{A}]+K_{\mathrm{a}}}+\mathrm{NS} \times[\mathrm{A}]
$$

where NS is the nonspecific binding.

In the presence of ligand depletion, binding is defined by

$$
\mathrm{TB}=\frac{B_{\max } \times\left([\mathrm{A}]_{\mathrm{T}}-\mathrm{TB}\right)}{\left([\mathrm{A}]_{\mathrm{T}}-\mathrm{TB}\right)+K_{\mathrm{a}}}+\left([\mathrm{A}]_{\mathrm{T}}-[\mathrm{TB}]\right) \times \mathrm{NS}
$$


where $[\mathrm{A}]_{\mathrm{T}}$ is the total radioligand concentration added. As TB appears on both sides of Equation 1.9 (implicit equation), it cannot be entered into most nonlinear regression programs. The equation can, however, be rearranged into a quadratic equation:

where

$$
\mathrm{TB}=\frac{-b+\sqrt{b^{2}-4 a c}}{2 a}
$$

$a=-1-\mathrm{NS}$

$b=[\mathrm{A}]_{\mathrm{T}}[2(\mathrm{NS}+1)]+K_{\mathrm{a}}(\mathrm{NS}+1)+B_{\max }$

and

$c=-[\mathrm{A}]_{\mathrm{T}}\left[\mathrm{NS}\left(K_{\mathrm{a}}+[\mathrm{A}]_{\mathrm{T}}\right)\right]+B_{\max }$

If total and nonspecific binding data are fitted globally, then nonspecific binding should be shared between datasets so that the fraction of total binding that is nonspecific at each radioligand concentration can be determined. This type of analysis will derive the $K_{\mathrm{a}}$ and the maximum level of binding of the radioligand without the need to subtract nonspecific from total binding. However, the raw data values that are derived from a saturation radioligand binding assay are usually more useful if converted to the amount of radioligand bound to our receptor preparation. We usually define the total number of binding sites in reference to the amount of protein or cells. For instance, $15 \mu \mathrm{g}$ protein were added into each tube of the saturation assay shown in Figure 1.3; therefore, $1.7 \mathrm{pmol}$ of receptor is expressed per milligram of protein.

\section{PROTOCOL 1.2 Saturation Binding Assays}

\section{Equipment and Reagents}

- Membrane preparation (Protocol 1.1)

- Binding buffer ${ }^{a}$

- $5 \mathrm{ml}$ polypropylene ${ }^{b}$ assay tubes (Techno-plas)

- Radioligand

- Competitive antagonist

- Wash buffer ${ }^{c}$

- Water bath

- Vacuum harvester (Brandel)

- Glass-fibre filter paper ${ }^{d}$ (Whatman)

- Liquid scintillation cocktaile (PerkinElmer)

- Liquid scintillation counter (e.g. Packard Tri-Carb LS counter).

\section{Method}

1 Dilute the receptor preparation, radioligand and competitive antagonist in assay buffer to $10 \times$ the final concentrations required in the assay, so that each can be diluted by this factor when added to the final assay mix. 
2 In an appropriate volume of binding buffer (usually between 0.5 and $1 \mathrm{ml}$ ), prepare one set of assay tubes containing increasing concentrations of radioligand and one identical set of tubes that also contain a saturating concentration of a competitive ligand to define nonspecific binding (see Table 1.1).

Table 1.1 Tube set-up used to determine saturation binding of $\left[{ }^{3} \mathrm{H}\right] \mathrm{NMS}$ to the $\mathrm{M}_{4}$ muscarinic ACh receptor using a $500 \mu$ f final assay volume, where nonspecific binding is determined in the presence of $10 \mu \mathrm{m}$ atropine.

\begin{tabular}{ccccc}
\hline $\begin{array}{c}\text { Final }\left[\left[{ }^{3} \mathrm{H}\right] \mathrm{NMS}\right] \\
(\mathrm{M})\end{array}$ & {$\left[\begin{array}{c}3 \mathrm{H}] \mathrm{NMS} \\
(\mu \mathrm{l})\end{array}\right.$} & $\begin{array}{c}100 \mu \mathrm{M} \\
\text { atropine }(10 \mu \mathrm{M} \\
\text { final concentration }) \\
\end{array}$ & $\begin{array}{c}\text { Buffer } \\
(\mu \mathrm{l})\end{array}$ & $\begin{array}{c}\text { Membrane } \\
(\mu \mathrm{l})\end{array}$ \\
\hline
\end{tabular}

\section{Total binding}

0

$1 \times 10^{-11}$

$3.16 \times 10^{-11}$

$1 \times 10^{-10}$

$3.16 \times 10^{-10}$

$1 \times 10^{-9}$

$3.16 \times 10^{-9}$

$1 \times 10^{-8}$
0

$$
\left.50 \text { (of } 1 \times 10^{-10} \mathrm{M}\right)
$$$$
160 \text { (of } 1 \times 10^{-10} \mathrm{M} \text { ) }
$$$$
50 \text { (of } 1 \times 10^{-9} \mathrm{M} \text { ) }
$$$$
160 \text { (of } 1 \times 10^{-9} \mathrm{M} \text { ) }
$$$$
50 \text { (of } 1 \times 10^{-8} \mathrm{M} \text { ) }
$$$$
160 \text { (of } 1 \times 10^{-8} \mathrm{M} \text { ) }
$$

50 (of $1 \times 10^{-7} \mathrm{M}$ )

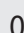

450

$0 \quad 400$

0

0

0

0

0

0

50

0

$1 \times 10^{-11}$

$3.16 \times 10^{-11}$

$1 \times 10^{-10}$

$3.16 \times 10^{-10}$

$1 \times 10^{-9}$

$3.16 \times 10^{-9}$

$1 \times 10^{-8}$
0

50 (of $1 \times 10^{-10} \mathrm{M}$ )

160 (of $1 \times 10^{-10} \mathrm{M}$ )

50 (of $1 \times 10^{-9} \mathrm{M}$ )

160 (of $1 \times 10^{-9} \mathrm{M}$ )

50 (of $1 \times 10^{-8} \mathrm{M}$ )

160 (of $1 \times 10^{-8} \mathrm{M}$ )

50 (of $1 \times 10^{-7} \mathrm{M}$ )
50

50

50

50

50

50

50
400

50

\section{0}

50

50

50

50

50

50

50

$400 \quad 50$

400

350

50

$240 \quad 50$

$350 \quad 50$

$240 \quad 50$

$350 \quad 50$

$240 \quad 50$

350

3 Start the binding reaction by addition of membrane protein, ${ }^{f}$ bringing the assay to the desired volume and incubate the reaction for sufficient time so as to reach equilibrium binding (at least five times the dissociation half-life of the ligand).

4 At the appropriate time, terminate the reaction by rapid vacuum filtration through glass-fibre filter paper followed by three to four $4 \mathrm{ml}$ washes with ice-cold wash buffer to separate bound from free radioligand.

5 Determine radioactivity by liquid scintillation counting. 


\section{Notes}

${ }^{a}$ For any radioligand binding assay, the buffer may be a simple buffer containing no or low concentrations of ions with chelating agents such as EDTA and EGTA (e.g. $20 \mathrm{~mm}$ HEPES, $1 \mathrm{~mm}$ EDTA, $1 \mathrm{~mm}$ EGTA, pH 7.4) or the buffer may resemble a more physiological environment or a buffer used for functional assays such as $\left[{ }^{35} \mathrm{~S}\right] \mathrm{GTP} \gamma \mathrm{S}$ binding assays (e.g. $20 \mathrm{~mm} \mathrm{HEPES,} 100 \mathrm{~mm}$ $\mathrm{NaCl}, 10 \mathrm{~mm} \mathrm{MgCl}, \mathrm{pH} 7.4$ ). Care should be taken when choosing the appropriate acid or base to adjust the $\mathrm{pH}$ of the buffer. Sodium hydroxide $(\mathrm{NaOH})$, for instance, will alter the concentration of sodium ions in the solution, which may have effects on the binding of ligands. $1-2 \mathrm{M} \mathrm{KOH}$ is more appropriate for adjusting the $\mathrm{pH}$ of radioligand binding buffers.

${ }^{b}$ Proteins and peptides are less likely to stick to polypropylene than to polystyrene-based plastics.

${ }^{C}$ PBS or other simple saline solution, such as $0.9 \% \mathrm{NaCl}$.

${ }^{d} \mathrm{GF} / \mathrm{B}$-grade glass-fibre filter paper has larger pores and, therefore, is generally better suited to cell-based binding assays, whilst GF/C-grade glass-fibre filter paper is better suited for membrane-based assays. However, higher nonspecific binding may be apparent when using $\mathrm{GF} / \mathrm{C}$-grade glass-fibre filter paper.

${ }^{e}$ Certain scintillation cocktails may be better suited to specific applications. For instance, whilst Perkin Elmer's Ultima Gold ${ }^{\mathrm{TM}}$ is suitable for both aqueous and nonaqueous samples, Irga Safe Plus $^{\mathrm{TM}}$ is more suited to aqueous samples.

${ }^{f}$ The appropriate protein concentration should be optimized prior to the performance of any ligand binding assay to ensure that ligand depletion does not occur.

\subsubsection{Heterologous and homologous competition binding experiments}

The use of high radioligand concentrations in saturation binding experiments can be expensive, whilst many ligands are unavailable in radioactive form, meaning that their affinity for a receptor cannot always be directly determined. Competition binding assays, however, are an alternative means to study interactions between the receptor and an unlabelled ligand under equilibrium conditions, by measuring the binding pattern of a single radioligand concentration in the presence of increasing concentrations of an unlabelled competitor (Protocol 1.3).

The concentration of the unlabelled ligand that causes $50 \%$ inhibition of radioligand binding is termed the $\mathrm{IC}_{50}$. However, this does not necessarily mean that this concentration of ligand will bind half the receptors, as the $\mathrm{IC}_{50}$ of the unlabelled ligand will depend upon the ability of the radioligand to bind to the receptor (e.g. its equilibrium dissociation constant), the ability of the unlabelled ligand to bind to the receptor and the concentration of the radiolabelled ligand. Thus, the $\mathrm{IC}_{50}$ will normally be greater than the equilibrium dissociation constant $K_{\mathrm{b}}$ of the unlabelled ligand. However, the Cheng-Prusoff equation (Equation 1.4) can be used to determine the $K_{\mathrm{b}}$ of the competitor in a competition binding experiment.

If one of the ligands being used for the assay is an agonist, then it may be desirable to eliminate, or at least minimize, the ability of the $\mathrm{G}$ protein to couple to the receptor, so that the interaction between the ligand and the receptor is largely independent of $\mathrm{G}$ protein coupling. For this reason, many researchers choose to perform agonist 
competition binding assays in the presence of guanine nucleotides and, hence, enable the data to be fitted to a simple one-site binding model. However, if the Hill coefficient of the inhibition curve is significantly different from unity, then this may indicate that the agonist binds to two different receptor species, which are usually described as a high- and low-affinity state. Under these circumstances, binding of the competitor to two sites may be the preferred model (see Equation 1.14).

An alternative approach to competition binding assays measures the competition between the radioligand and a non-radiolabelled version of the radioligand. This type of competition assay is called homologous competition binding [17]. It can be utilized to determine the affinity of the radioligand for a receptor in addition to the number of binding sites present, if the radioligand, A, and unlabelled competitor, B, share an identical affinity for the receptor. Under these circumstances, binding of the radioligand will be a fraction of the total ligand bound $([\mathrm{A}]+[\mathrm{B}])$ and will be defined by

$$
[\mathrm{AR}]=\frac{[\mathrm{A}] \times\left[\mathrm{R}_{\mathrm{t}}\right]}{[\mathrm{A}]+[\mathrm{B}]+K_{\mathrm{a}}}
$$

where

$$
K_{\mathrm{a}}=\mathrm{IC}_{50}-[\mathrm{A}]
$$

If we consider a heterologous competition binding assay, binding of a radioligand, expressed on the $y$-axis, in the presence of increasing concentrations of a competitor, expressed on the $x$-axis, will follow a sigmoidal curve that can be described by Equation 1.3 (see Figure 1.4). Depending on the nonlinear regression program used to analyse the data, the program must be told to define parameters in a logarithmic

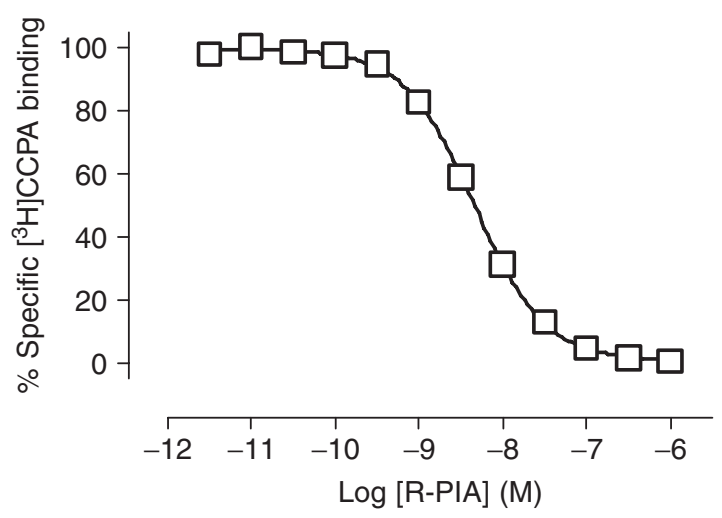

Figure 1.4 Competition binding of the radiolabelled agonist, $\left[{ }^{3} \mathrm{H}\right] 2$-chloro- $N^{6}$-cyclopentyladenosine $\left(\left[{ }^{3} \mathrm{H}\right] \mathrm{CCPA}\right)$, at the $\mathrm{A}_{1}$ adenosine receptor by increasing concentrations of the unlabelled agonist, $N^{6}-((R)$-2-phenylisopropyl)adenosine (R-PIA). Membranes were incubated with $\left[{ }^{3} \mathrm{H}\right]$ CCPA and R-PIA for $1 \mathrm{~h}$ at $30^{\circ} \mathrm{C}$ before termination of the assay as described in the methods section. Data were transformed to the percentage of specific $\left[{ }^{3} \mathrm{H}\right] \mathrm{CCPA}$ binding and fitted closely to a model that described one-site binding with a Hill coefficient of unity. 
form if this is how they are to be reported. Alternatively, Equation 1.3 can be recast to reflect this, as shown by the following

$$
Y=\frac{\text { Top }- \text { Bottom }}{1+10^{\left(\log [\mathrm{B}]-\log \mathrm{IC}_{50}\right) n}}+\text { Bottom }
$$

If the Hill coefficient $n$ is not significantly different from unity, then this may be constrained as such in the analysis. If, however, it appears to vary from unity, then the data may sometimes be fitted best by a two-site binding model:

$$
Y=(\text { Top }- \text { Bottom })\left(\frac{\text { fraction } \_1}{1+10^{\log [\mathrm{B}]-\log I \mathrm{IC}_{50 \_1}}}+\frac{1-\text { fraction } \_1}{1+10^{\log [\mathrm{B}]-\log \mathrm{IC}_{50} 2}}\right)+\text { Bottom }
$$

For analysis of homologous binding data we can use Equation 1.15 to define binding:

$$
Y=\frac{\text { Top }- \text { Bottom }}{1+10^{\log [\mathrm{B}]-\log [\mathrm{A}]}+10^{\log K_{\mathrm{a}}-\log [\mathrm{A}]}}+\text { Bottom }
$$

\section{PROTOCOL 1.3 Competition Binding Assays}

\section{Equipment and Reagents}

- Membrane preparation (Protocol 1.1)

- Binding buffer ${ }^{a}$

- $5 \mathrm{ml}$ polypropylene assay tubes (Techno-plas)

- Radioligand ${ }^{b}$

- Unlabelled ligand ${ }^{c}$

- Guanine nucleotide ${ }^{d}$ (Sigma)

- Wash buffer ${ }^{e}$

- Water bath

- Vacuum harvester (Brandel)

- Glass-fibre filter paper (Whatman)

- Liquid scintillation cocktail (PerkinElmer)

- Liquid scintillation counter (e.g. Packard Tri-Carb LS counter).

\section{Method}

1 Dilute the receptor preparation, radioligand, unlabelled ligand and guanine nucleotides (if required) in assay buffer to $10 \times$ the final concentration desired in the assay.

2 In an appropriate volume of binding buffer, add a single concentration of radioligand to all assay tubes and add increasing concentrations of the unlabelled ligand into different tubes. Ensure that you prepare tubes in which no unlabelled ligand is added to define 
total binding, in addition to tubes that contain no unlabelled ligand but a high concentration of an alternative competitive ligand to define nonspecific binding. If desired, add an appropriate concentration of guanine nucleotides to each tube to minimize $\mathrm{G}$ protein coupling to the receptor (see Table 1.2).

Table 1.2 Tube set-up used to determine binding of $\left[{ }^{3} \mathrm{H}\right] \mathrm{CCPA}$ in the presence of increasing concentrations of R-PIA using a $500 \mu$ f final assay volume, where nonspecific binding is determined in the presence of $100 \mu \mathrm{M}$ R-PIA.

\begin{tabular}{|c|c|c|c|c|c|}
\hline $\begin{array}{l}\text { Final [R-PIA] } \\
\text { (M) }\end{array}$ & R-PIA & $\begin{array}{c}1 \text { mм GppNHp } \\
(100 \mu \text { m final } \\
\text { concentration }) \\
(\mu \mathrm{l})\end{array}$ & $\begin{array}{l}\text { Buffer } \\
(\mu \mathrm{l})\end{array}$ & $\begin{array}{c}20 \mathrm{~nm}\left[{ }^{3} \mathrm{H}\right] \mathrm{CCPA} \\
(2 \mathrm{~nm} \text { final } \\
\text { concentration }) \\
(\mu \mathrm{l})\end{array}$ & $\begin{array}{c}\text { Membrane } \\
(\mu \mathrm{l})\end{array}$ \\
\hline 0 & 0 & 50 & 350 & 50 & 50 \\
\hline $3.16 \times 10^{-11}$ & $160\left(\right.$ of $\left.1 \times 10^{-10} \mathrm{M}\right)$ & 50 & 190 & 50 & 50 \\
\hline $1 \times 10^{-10}$ & $50\left(\right.$ of $\left.1 \times 10^{-9} \mathrm{M}\right)$ & 50 & 300 & 50 & 50 \\
\hline $3.16 \times 10^{-10}$ & $160\left(\right.$ of $\left.1 \times 10^{-9} \mathrm{M}\right)$ & 50 & 190 & 50 & 50 \\
\hline $1 \times 10^{-9}$ & $50\left(\right.$ of $\left.1 \times 10^{-8} \mathrm{M}\right)$ & 50 & 300 & 50 & 50 \\
\hline $3.16 \times 10^{-9}$ & $160\left(\right.$ of $\left.1 \times 10^{-8} \mathrm{M}\right)$ & 50 & 190 & 50 & 50 \\
\hline $1 \times 10^{-8}$ & $50\left(\right.$ of $\left.1 \times 10^{-7} \mathrm{M}\right)$ & 50 & 300 & 50 & 50 \\
\hline $3.16 \times 10^{-8}$ & $160\left(\right.$ of $\left.1 \times 10^{-7} \mathrm{M}\right)$ & 50 & 190 & 50 & 50 \\
\hline $1 \times 10^{-7}$ & $50\left(\right.$ of $\left.1 \times 10^{-6} \mathrm{M}\right)$ & 50 & 300 & 50 & 50 \\
\hline $3.16 \times 10^{-7}$ & $160\left(\right.$ of $\left.1 \times 10^{-6} \mathrm{M}\right)$ & 50 & 190 & 50 & 50 \\
\hline $1 \times 10^{-6}$ & $50\left(\right.$ of $\left.1 \times 10^{-5} \mathrm{M}\right)$ & 50 & 300 & 50 & 50 \\
\hline $\begin{array}{l}\text { Nonspecific } \\
\text { binding }\end{array}$ & $50\left(\right.$ of $\left.1 \times 10^{-3} \mathrm{M}\right)$ & 50 & 300 & 50 & 50 \\
\hline
\end{tabular}

3 Start the reaction by the addition of membrane and incubate the assay for the desired time so as to reach equilibrium binding.

4 Terminate the reaction and determine radioactivity as described in Protocol 1.2.

\section{Notes}

${ }^{a}$ As described in Protocol 1.2.

${ }^{b}$ The radioligand concentration should be approximately equal to its $K_{\mathrm{a}}$ or lower.

'This will be an unlabelled form of the radioligand for homologous competition binding assays, or an alternative unlabelled ligand for heterologous competition binding assays.

${ }^{d}$ If guanine nucleotides are to be added to the assay, $100 \mu \mathrm{M}$ GppNHp or $1 \mathrm{mM}$ GTP is generally sufficient to uncouple receptor $-G$ protein complexes.

${ }^{e}$ As described in Protocol 1.2. 


\subsubsection{Equilibrium binding experiments with an allosteric modulator}

Saturation assays performed in the absence and presence of a putative allosteric modulator are a useful means to determine whether a shift in radioligand affinity in the presence of the modulator is in agreement with an allosteric mode of action (Protocol 1.4). For a competitive ligand, if the ratio of the affinity of the radioligand in the presence $\left(K_{\mathrm{a}}^{\prime}\right)$ and absence $\left(K_{\mathrm{a}}\right)$ of this competitor, otherwise known as the 'dose ratio', is determined, then a Schild plot of $\log \left[\left(K_{\mathrm{a}}^{\prime} / K_{\mathrm{a}}\right)-1\right]$ against the log competitor concentration should yield a straight line with a slope of unity [18]. If, however, there is negative cooperativity between the putative modulator and the orthosteric ligand, then the slope may differ from unity and a curvilinear plot may result. The curvature in the Schild plot will represent the cooperativity between the two ligands, reflecting a limit in the shift in the radioligand affinity. Positive allosteric interactions, in contrast, can be characterized by an enhancement in the affinity of the radioligand, causing a leftward shift in the radioligand binding curve. Under these circumstances, the dose ratio can be determined as the ratio of radioligand affinities in the absence and presence of the allosteric modulator and a Schild plot of $\log \left(K_{\mathrm{a}} / K_{\mathrm{a}}^{\prime}\right)$ against the $\log$ modulator concentration may reflect the positive cooperativity [8].

Competition binding assays may also be used to study the direct effects of an allosteric modulator on the binding of a radioligand at the orthosteric site; although the allosteric modulator will not directly compete for binding with the orthosteric radioligand, the cooperativity will mediate alterations in the binding of the radioligand.

If we consider the scheme shown in Figure 1.2, then fractional occupancy of a receptor population by the orthosteric ligand $[\mathrm{A}]$ in the presence of an allosteric modulator [B] can be described by

$$
\rho_{\mathrm{AR}+\mathrm{ARB}}=\frac{B_{\max } \times[\mathrm{A}]}{[\mathrm{A}]+K_{\mathrm{a}}\left[\left(1+\frac{[\mathrm{B}]}{K_{\mathrm{b}}}\right) /\left(1+\frac{\alpha[\mathrm{B}]}{K_{\mathrm{b}}}\right)\right]}
$$

Note that the apparent affinity $K_{\text {app }}$ of the radioligand in the presence of the allosteric modulator is defined by

$$
K_{\text {app }}=K_{\mathrm{a}} \frac{1+\frac{[\mathrm{B}]}{K_{\mathrm{b}}}}{1+\frac{\alpha[\mathrm{B}]}{K_{\mathrm{b}}}}
$$

Care must be taken when choosing the radioligand concentration for such assays. If the allosteric modulator has very high negative cooperativity with the radioligand, it may appear competitive if a low radioligand concentration is employed giving rise to low radioligand receptor occupancy. As the radioligand concentration is increased, the ability of the allosteric modulator to inhibit radioligand binding will be reduced, which is seen by an increase in the bottom asymptote of the inhibition curve. Subsequently, full inhibition by the allosteric modulator may not be achieved using high radioligand concentrations, preventing its actions from being distinguished from a competitive antagonist (see Figure 1.5). However, nonequilibrium binding artefacts may greatly 


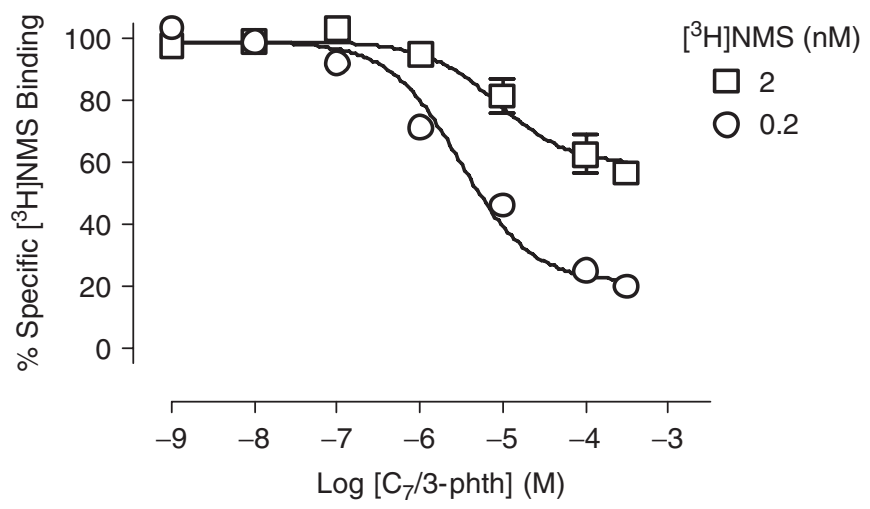

Figure 1.5 Normalized binding of two different concentrations of the radioligand, $\left[{ }^{3} \mathrm{H}\right] \mathrm{NMS}$, at the $M_{4}$ muscarinic ACh receptor in the presence of increasing concentrations of the muscarinic receptor allosteric modulator, heptane-1,7-bis(dimethyl-3'-phthalimidopropyl)ammonium bromide ( $C_{7} / 3$-phth). Membranes were incubated with $C_{7} / 3$-phth for $1 \mathrm{~h}$ at $37^{\circ} \mathrm{C}$ before the assay was terminated as described in Section 1.2.

influence the results obtained in such an experiment and care must be taken to interpret the observations correctly [19].

Several alternative approaches have been described to determine the effects that the allosteric modulator can exert [10,20]. One approach is to compete radioligand binding with an unlabelled competitive ligand in the presence of different concentrations of allosteric modulator [20], which can give detailed information regarding the interaction of the allosteric modulator with both the radioligand and the orthosteric competitor (Protocol 1.4).

The assay described in Protocol 1.4 can be used to determine the cooperativity between the allosteric modulator and both the radioligand and unlabelled competitor, where binding of the radioligand $[\mathrm{A}]$ in the presence of the competitor $[\mathrm{B}]$ and the allosteric modulator $[\mathrm{X}]$ is described by

$$
Y=\frac{B_{\max } \times[\mathrm{A}]}{[\mathrm{A}]+\left(\frac{K_{\mathrm{a}} K_{\mathrm{X}}}{\alpha[\mathrm{X}]+K_{\mathrm{X}}}\right)\left(1+\frac{[\mathrm{B}]}{K_{\mathrm{b}}}+\frac{[\mathrm{X}]}{K_{\mathrm{b}}}+\frac{\beta[\mathrm{B}] \times[\mathrm{X}]}{K_{\mathrm{b}} K_{\mathrm{X}}}\right)}
$$

where $K_{\mathrm{a}}, K_{\mathrm{b}}$ and $K_{\mathrm{X}}$ are the equilibrium dissociation constants of the radioligand, competitor and allosteric modulator respectively. Figure 1.6 shows competition binding at the $\mathrm{M}_{4}$ muscarinic $\mathrm{ACh}$ receptor in the absence and presence of an allosteric modulator, which exerts weak negative cooperativity with the radioligand, $\left[{ }^{3} \mathrm{H}\right] \mathrm{NMS}$. In contrast, however, the same modulator exerts positive cooperativity with ACh, demonstrated by the leftward shift in the apparent ability of ACh to compete for $\left[{ }^{3} \mathrm{H}\right] \mathrm{NMS}$ binding. 


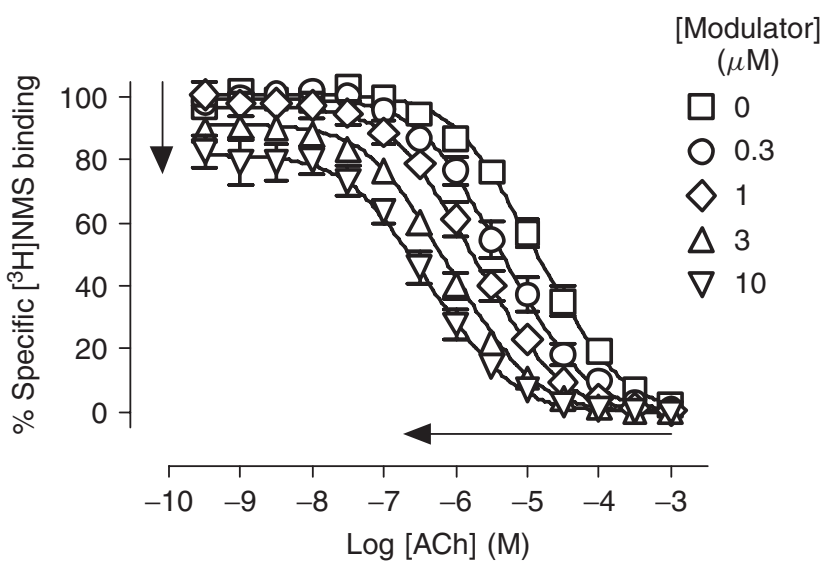

Figure 1.6 Competition of binding of the radioligand, $\left[{ }^{3} \mathrm{H}\right] \mathrm{NMS}$, at the $\mathrm{M}_{4}$ muscarinic $\mathrm{ACh}$ receptor by increasing concentrations of the agonist, $\mathrm{ACh}$, in the absence and presence of increasing concentrations of an allosteric potentiator of ACh binding. Membranes were equilibrated with $\mathrm{ACh}$ and the allosteric modulator for $3 \mathrm{~h}$ at $37^{\circ} \mathrm{C}$ before termination of the assay as described in Section 1.2.

\section{PROTOCOL 1.4 Orthosteric Radioligand Binding in the Presence of an Allosteric Modulator}

\section{Equipment and Reagents}

- Membrane preparation (Protocol 1.1)

- Binding buffer ${ }^{a}$

- $5 \mathrm{ml}$ polypropylene assay tubes (Techno-plas)

- Radioligand ${ }^{b}$

- Unlabelled competitor

- Allosteric modulator

- Guanine nucleotides ${ }^{c}$ (Sigma)

- Wash buffer ${ }^{d}$

- Water bath

- Vacuum harvester (Brandel)

- Glass-fibre filter paper (Whatman)

- Liquid scintillation cocktail (PerkinElmer)

- Liquid scintillation counter (e.g. Packard Tri-Carb LS counter). 


\section{Method}

1 Dilute the receptor preparation, radioligand, unlabelled competitor, allosteric modulator and guanine nucleotides (if required) in assay buffer to $10 \times$ the final concentration desired in the assay.

2 In an appropriate volume of binding buffer, add a single concentration of radioligand to all tubes.

3 For a control curve in the absence of allosteric modulator, add increasing concentrations of the unlabelled competitive ligand into different tubes. Remember to prepare tubes in which no unlabelled ligand is added to define total binding, in addition to tubes that contain no unlabelled ligand but a high concentration of an alternative competitive ligand to define nonspecific binding.

4 To a second set of tubes, add increasing concentrations of the unlabelled ligand into different tubes in addition to the allosteric modulator. Several concentrations of modulator should be tested. If each concentration-response curve will be harvested separately, for every curve derived in the presence of the allosteric modulator, prepare tubes in which no unlabelled ligand is added but the allosteric modulator is present, to define total binding in the presence of the modulator, in addition to tubes that contain no unlabelled ligand and no allosteric modulator. This will account for variation between total binding counts on different pieces of filter paper. The total binding in the absence of allosteric modulator can be used to transform data if the allosteric modulator shows negative or positive cooperativity with the radioligand and, therefore, reduces or increases its binding. Also ensure that the vehicle in which the allosteric modulator is prepared exerts no effect on radioligand binding. In addition, prepare tubes that contain no unlabelled ligand but a high concentration of a different competitive ligand to define nonspecific binding (see Table 1.3).

Table 1.3 Tube set-up used to determine the binding of $\left[{ }^{3} \mathrm{H}\right] \mathrm{NMS}$ to the $\mathrm{M}_{4}$ muscarinic $\mathrm{ACh}$ receptor in the presence of increasing concentrations of $\mathrm{ACh}$ and an allosteric modulator, using a $500 \mu \mathrm{l}$ final assay volume, where nonspecific binding is determined in the presence of atropine.

\begin{tabular}{|c|c|c|c|c|c|c|}
\hline $\begin{array}{l}\text { Final }[\mathrm{ACh}] \\
\text { (M) }\end{array}$ & $\mathrm{ACh}(\mu \mathrm{l})$ & $\begin{array}{c}\text { Allosteric } \\
\text { modulator } \\
(\mu \mathrm{l})\end{array}$ & $\begin{array}{c}1 \mathrm{~mm} \text { GppNHp } \\
(100 \mu \mathrm{M} \text { final } \\
\text { concentration }) \\
(\mu \mathrm{l})\end{array}$ & $\begin{array}{l}\text { Buffer } \\
(\mu l)\end{array}$ & $\begin{array}{c}2 \mathrm{nM}\left[{ }^{3} \mathrm{H}\right] \mathrm{NMS} \\
(0.2 \mathrm{~nm} \text { final } \\
\text { concentration }) \\
(\mu \mathrm{l})\end{array}$ & $\begin{array}{c}\text { Membrane } \\
(\mu \mathrm{l})\end{array}$ \\
\hline
\end{tabular}

Control curve in the absence of allosteric modulator

\begin{tabular}{lllllll}
0 & 0 & 0 & 50 & 350 & 50 & 50 \\
$1 \times 10^{-9}$ & $50\left(\right.$ of $\left.1 \times 10^{-8} \mathrm{M}\right)$ & 0 & 50 & 300 & 50 & 50 \\
$3.16 \times 10^{-9}$ & $160\left(\right.$ of $\left.1 \times 10^{-8} \mathrm{M}\right)$ & 0 & 50 & 190 & 50 & 50 \\
$1 \times 10^{-8}$ & $50\left(\right.$ of $\left.1 \times 10^{-7} \mathrm{M}\right)$ & 0 & 50 & 300 & 50 & 50 \\
$3.16 \times 10^{-8}$ & $160\left(\right.$ of $\left.1 \times 10^{-7} \mathrm{M}\right)$ & 0 & 50 & 190 & 50 & 50 \\
$1 \times 10^{-7}$ & $50\left(\right.$ of $\left.1 \times 10^{-6} \mathrm{M}\right)$ & 0 & 50 & 300 & 50 & 50 \\
$3.16 \times 10^{-7}$ & $160\left(\right.$ of $\left.1 \times 10^{-6} \mathrm{M}\right)$ & 0 & 50 & 190 & 50 & 50 \\
$1 \times 10^{-6}$ & $50\left(\right.$ of $\left.1 \times 10^{-5} \mathrm{M}\right)$ & 0 & 50 & 300 & 50 & 50 \\
\hline & & & & & & (continued overleaf)
\end{tabular}


Table 1.3 (continued)

Final $[\mathrm{ACh}] \quad \mathrm{ACh}(\mu \mathrm{l})$
$(\mathrm{M})$

Allosteric $1 \mathrm{~mm}$ GppNHp Buffer $2 \mathrm{~nm}\left[{ }^{3} \mathrm{H}\right] \mathrm{NMS}$ Membrane modulator $(100 \mu \mathrm{m}$ final $(\mu \mathrm{l}) \quad(0.2 \mathrm{~nm}$ final

$(\mu \mathrm{l})$ $(\mu \mathrm{l}) \quad$ concentration) concentration)

$(\mu \mathrm{l})$ $(\mu \mathrm{l})$

\begin{tabular}{ll}
\hline $3.16 \times 10^{-6}$ & $160\left(\right.$ of $\left.1 \times 10^{-5} \mathrm{M}\right)$ \\
$1 \times 10^{-5}$ & $50\left(\right.$ of $\left.1 \times 10^{-4} \mathrm{M}\right)$ \\
$3.16 \times 10^{-5}$ & $160\left(\right.$ of $\left.1 \times 10^{-4} \mathrm{M}\right)$ \\
$1 \times 10^{-4}$ & $50\left(\right.$ of $\left.1 \times 10^{-3} \mathrm{M}\right)$ \\
$3.16 \times 10^{-4}$ & $160\left(\right.$ of $\left.1 \times 10^{-3} \mathrm{M}\right)$ \\
$1 \times 10^{-3}$ & $50\left(\right.$ of $\left.1 \times 10^{-2} \mathrm{M}\right)$ \\
$\begin{array}{c}\text { Nonspecific } \\
\text { binding }\end{array}$ & $50($ of $100 \mu \mathrm{M})$ \\
& atropine
\end{tabular}

$50 \quad 190$

50

Curve in the presence of allosteric modulator

\begin{tabular}{|c|c|c|c|c|c|c|}
\hline Vehicle control & 50 vehicle & 0 & 50 & 300 & 50 & 50 \\
\hline Total binding & 0 & 0 & 50 & 350 & 50 & 50 \\
\hline 0 & 0 & 50 & 50 & 300 & 50 & 50 \\
\hline $1 \times 10^{-9}$ & $50\left(\right.$ of $\left.1 \times 10^{-8} \mathrm{M}\right)$ & 50 & 50 & 250 & 50 & 50 \\
\hline $3.16 \times 10^{-9}$ & $160\left(\right.$ of $\left.1 \times 10^{-8} \mathrm{M}\right)$ & 50 & 50 & 140 & 50 & 50 \\
\hline $1 \times 10^{-8}$ & $50\left(\right.$ of $\left.1 \times 10^{-7} \mathrm{M}\right)$ & 50 & 50 & 250 & 50 & 50 \\
\hline $3.16 \times 10^{-8}$ & $160\left(\right.$ of $\left.1 \times 10^{-7} \mathrm{M}\right)$ & 50 & 50 & 140 & 50 & 50 \\
\hline $1 \times 10^{-7}$ & $50\left(\right.$ of $\left.1 \times 10^{-6} \mathrm{M}\right)$ & 50 & 50 & 250 & 50 & 50 \\
\hline $3.16 \times 10^{-7}$ & $160\left(\right.$ of $\left.1 \times 10^{-6} \mathrm{M}\right)$ & 50 & 50 & 140 & 50 & 50 \\
\hline $1 \times 10^{-6}$ & $50\left(\right.$ of $\left.1 \times 10^{-5} \mathrm{M}\right)$ & 50 & 50 & 250 & 50 & 50 \\
\hline $3.16 \times 10^{-6}$ & $160\left(\right.$ of $\left.1 \times 10^{-5} \mathrm{M}\right)$ & 50 & 50 & 140 & 50 & 50 \\
\hline $1 \times 10^{-5}$ & $50\left(\right.$ of $\left.1 \times 10^{-4} \mathrm{M}\right)$ & 50 & 50 & 250 & 50 & 50 \\
\hline $3.16 \times 10^{-5}$ & $160\left(\right.$ of $\left.1 \times 10^{-4} \mathrm{M}\right)$ & 50 & 50 & 140 & 50 & 50 \\
\hline $1 \times 10^{-4}$ & $50\left(\right.$ of $\left.1 \times 10^{-3} \mathrm{M}\right)$ & 50 & 50 & 250 & 50 & 50 \\
\hline $3.16 \times 10^{-4}$ & $160\left(\right.$ of $\left.1 \times 10^{-3} \mathrm{M}\right)$ & 50 & 50 & 140 & 50 & 50 \\
\hline $1 \times 10^{-3}$ & $50\left(\right.$ of $\left.1 \times 10^{-2} \mathrm{M}\right)$ & 50 & 50 & 250 & 50 & 50 \\
\hline $\begin{array}{c}\text { Nonspecific } \\
\text { binding }\end{array}$ & $\begin{array}{c}50(\text { of } 100 \mu \mathrm{M}) \\
\text { atropine }\end{array}$ & 50 DMSO & 50 & 250 & 50 & 50 \\
\hline
\end{tabular}

5 Start the reaction by the addition of membrane and incubate the assay for the desired time so as to reach equilibrium binding.

6 Terminate the reaction and determine radioactivity as described in Protocol 1.2.

\section{Notes}

${ }^{a}$ As described in Protocol 1.2.

${ }^{b}$ The radioligand concentration should approximately equal its $K_{\mathrm{a}}$.

'See note $d$ in Protocol 1.3.

${ }^{d}$ As described in Protocol 1.2. 


\subsubsection{Kinetic radioligand binding assays}

Kinetic assays can be used to determine the association or dissociation rate constants of a radioligand (Protocol 1.5). This information is useful, for instance, for deciding the correct incubation time for many radioligands to reach equilibrium conditions so that equilibrium dissociation and association constants can be accurately measured in subsequent assays [21]. Kinetic assays can additionally be used to reveal cooperativity between two binding sites, where the binding kinetics of the orthosteric ligand may be modulated.

Method 1 in Protocol 1.5 describes measurement of the time taken to reach equilibrium binding, which will be represented by a plateau in the binding curve over time. The rate at which equilibrium is reached is dependent on the radioligand concentration and the rate at which the ligand associates with and dissociates from the receptor.

In the presence of a single radioligand concentration, this information can be used to calculate the association rate constant $K_{\text {on }}$ only if the rate at which the ligand dissociates from the receptor $K_{\text {off }}$ is known. If $K_{\text {off }}$ is known, then we can use Equation 1.19 to calculate $K_{\text {on }}$ :

$$
K_{\mathrm{on}}=\frac{K_{\mathrm{obs}}-K_{\mathrm{off}}}{[\mathrm{A}]}
$$

However, if the $K_{\text {off }}$ of the ligand is unknown, then both $K_{\text {on }}$ and $K_{\text {off }}$ can be determined by measuring the $K_{\mathrm{obs}}$ of multiple concentrations of radioligand. Traditionally, $K_{\text {obs }}$ (in inverse time) is plotted against the inverse radioligand concentration to derive a straight line with a gradient equal to $K_{\text {on }}$ and a $y$-intercept equal to $K_{\text {off }}$. Alternatively, the $K_{\mathrm{obs}}$ of at least two different concentrations of radioligand can be fitted globally to the kinetic model shown in Equation 1.6. Otherwise, the rate of radioligand association can be determined by measuring both the association and dissociation of the radioligand in one experiment. A kinetic assay of this kind allows us to measure the dissociation rate of the radioligand directly in inverse time and will yield the $K_{\mathrm{obs}}$, as described for association experiments; so, if we know the radioligand concentration, then we can define occupancy over time using Equation 1.6.

\section{PROTOCOL 1.5 Measurement of Radioligand Binding Kinetics}

\section{Equipment and Reagents}

- Membrane preparation (Protocol 1.1)

- Binding buffer ${ }^{a}$

- $5 \mathrm{ml}$ polypropylene assay tubes (Techno-plas)

- Radioligand

- Competitive ligand

- Wash buffer ${ }^{b}$

- Water bath

- Vacuum harvester (Brandel) 
- Glass-fibre filter paper (Whatman)

- Liquid scintillation cocktail (PerkinElmer)

- Liquid scintillation counter (e.g. Packard Tri-Carb LS counter).

\section{Method 1: Association Binding Kinetics}

1 Dilute the receptor preparation, radioligand and competitive ligand in assay buffer to $10 \times$ the final concentration desired in the assay.

2 Prepare tubes containing the radioligand and identical tubes also containing a saturating concentration of a competitive ligand to define nonspecific binding. ${ }^{c}$ Tubes that contain no radioligand must also be prepared to represent binding of the radioligand at the zero time point (i.e. no radioligand binding). Membrane can be added to these tubes before the start of the assay, as the values obtained from these tubes will purely be representative of background counts that arise from sources other than the radioligand.

3 Stagger the addition of membrane, bringing the assay to the desired final volume, so that binding of the radioligand can be determined at various time points. For instance, add membrane to the first tube at time point 0 and make subsequent membrane additions to successive tubes at 5, 10, 15 and $18 \mathrm{~min}$. Separate bound from free radioligand (as described in Protocol 1.2) at $20 \mathrm{~min}$. Thus, tubes containing membrane added at time points $0,5,10,15$ and 18 min will represent 20, 15, 10, 5 and 2 min incubation between the membrane and radioligand respectively, whilst tubes containing membrane but no radioligand will represent time point 0 (see Table 1.4).

Table 1.4 Tube set-up used to determine the binding of $\left[{ }^{3} \mathrm{H}\right] \mathrm{NMS}$ to the $\mathrm{M}_{4}$ muscarinic ACh receptor over time, using a $1 \mathrm{ml}$ final assay volume, where nonspecific binding is determined in the presence of atropine.

\begin{tabular}{lccccc}
\hline Time of & Association & $2 \mathrm{~nm}\left[{ }^{3} \mathrm{H}\right] \mathrm{NMS}$ & Buffer & $100 \mu$ M Atropine & Membrane \\
{$\left[{ }^{3} \mathrm{H}\right]$ NMS } & time & $(0.2 \mathrm{~nm}$ final & $(\mu \mathrm{l})$ & $(10 \mu$ m final & $(\mu \mathrm{l})$ \\
$\begin{array}{l}\text { addition } \\
\text { (min) }\end{array}$ & $(\mathrm{min})$ & concentration $)$ & & concentration $)$ & $(\mu \mathrm{l})$ \\
\hline
\end{tabular}

Specific binding

\begin{tabular}{rrrrrr}
0 & 20 & 100 & 800 & 0 & 100 \\
5 & 15 & 100 & 800 & 0 & 100 \\
10 & 10 & 100 & 800 & 0 & 100 \\
15 & 5 & 100 & 800 & 0 & 100 \\
18 & 2 & 100 & 800 & 0 & 100 \\
- & 0 & 0 & 900 & 0 & 100 \\
\hline
\end{tabular}


Table 1.4 (continued)

\begin{tabular}{lccccc}
\hline Time of & Association & $2 \mathrm{~nm}\left[{ }^{3} \mathrm{H}\right] \mathrm{NMS}$ & Buffer & $100 \mu \mathrm{m}$ Atropine & Membrane \\
{$\left[{ }^{3} \mathrm{H}\right] \mathrm{NMS}$} & time & $(0.2 \mathrm{~nm}$ final & $(\mu \mathrm{l})$ & $(10 \mu \mathrm{m}$ final & $(\mu \mathrm{l})$ \\
$\begin{array}{l}\text { addition } \\
(\mathrm{min})\end{array}$ & $(\mathrm{min})$ & $\begin{array}{c}\text { concentration }) \\
(\mu \mathrm{l})\end{array}$ & $\begin{array}{c}\text { concentration }) \\
(\mu \mathrm{l})\end{array}$ & \\
\hline
\end{tabular}

Nonspecific binding

\begin{tabular}{rrrrrr}
0 & 20 & 100 & 700 & 100 & 100 \\
5 & 15 & 100 & 700 & 100 & 100 \\
10 & 10 & 100 & 700 & 100 & 100 \\
15 & 5 & 100 & 700 & 100 & 100 \\
18 & 2 & 100 & 700 & 100 & 100 \\
- & 0 & 0 & 800 & 100 & 100 \\
\hline
\end{tabular}

4 Determine radioactivity as described in Protocol 1.2.

\section{Method 2: Dissociation Binding Kinetics}

1 Dilute the receptor preparation and radioligand in assay buffer to $10 \times$ the final concentration desired in the assay. Dilute the competitive ligand to $100000 \times$ its $K_{\mathrm{a}}$ value, as this will be diluted $100 \times$ into the assay, so the final concentration of competitive ligand will be $1000 \times$ its $K_{\mathrm{a}}$.

2 Prepare tubes containing the radioligand. Also prepare one set of tubes containing a saturating concentration of a competitive ligand to define nonspecific binding at each time point.

3 Stagger the addition of membrane to each tube so that the membrane is incubated with the radioligand for the same amount of time in each tube prior to the addition of competitor (see Table 1.5).

Table 1.5 Tube set-up to determine the dissociation kinetics of $\left[{ }^{3} \mathrm{H}\right] \mathrm{NMS}$ from the $\mathrm{M}_{4}$ muscarinic ACh receptor over time, using a $1 \mathrm{ml}$ final assay volume.

\begin{tabular}{lcccccc}
\hline $\begin{array}{l}\text { Time of } \\
\text { membrane } \\
\begin{array}{c}\text { addition } \\
(\mathrm{min})\end{array}\end{array}$ & $\begin{array}{c}\text { Time of } \\
\text { atropine } \\
\text { addition } \\
(\mathrm{min})\end{array}$ & $\begin{array}{c}\text { Dissociation } \\
\text { time } \\
(\mathrm{min})\end{array}$ & $\begin{array}{c}2 \mathrm{nM}\left[{ }^{3} \mathrm{H}\right] \mathrm{NMS} \\
(0.2 \mathrm{~nm} \text { final } \\
\text { concentration }) \\
(\mu \mathrm{l})\end{array}$ & Buffer & Membrane & $\begin{array}{c}1 \mathrm{~mm} \text { Atropine } \\
(10 \mu \mathrm{m} \\
\text { final }\end{array}$ \\
\hline 0 & 60 & 20 & 100 & 800 & 100 & 10 \\
5 & 65 & 15 & 100 & 800 & 100 & 10 \\
10 & 70 & 10 & 100 & 800 & 100 & 10 \\
\hline
\end{tabular}


Table 1.5 (continued)

\begin{tabular}{lcccccc}
\hline $\begin{array}{l}\text { Time of } \\
\text { membrane } \\
\begin{array}{l}\text { addition } \\
(\mathrm{min})\end{array}\end{array}$ & $\begin{array}{c}\text { Time of } \\
\text { atropine } \\
\text { addition } \\
(\mathrm{min})\end{array}$ & $\begin{array}{c}\text { Dissociation } \\
\text { time } \\
(\mathrm{min})\end{array}$ & $\begin{array}{c}2 \mathrm{nM}\left[{ }^{3} \mathrm{H}\right] \mathrm{NMS} \\
(0.2 \mathrm{~nm} \text { final } \\
\text { concentration })\end{array}$ & Buffer & Membrane & $\begin{array}{c}1 \mathrm{~mm} \text { Atropine } \\
(10 \mu \mathrm{M}) \\
\text { final }\end{array}$ \\
\hline 15 & 75 & 5 & 100 & 800 & 100 & 10 \\
18 & 78 & 2 & 100 & 800 & 100 & 10 \\
20 & - & 0 & 100 & 800 & 100 & 0 \\
\hline
\end{tabular}

Note that this tube set-up can be used for both specific and nonspecific binding; however, for nonspecific binding, atropine must be present throughout the entire incubation period that the receptor is incubated with $\left[{ }^{3} \mathrm{H}\right] \mathrm{NMS}$, rather than staggering its addition following equilibrium binding of $\left[{ }^{3} \mathrm{H}\right] \mathrm{NMS}$.

4 Following equilibrium binding of the radioligand with the receptor, ${ }^{d}$ stagger the addition of a small volume $(\sim 10 \mu \mathrm{l}$ to minimize adjustment of the assay volume and, thus, prevent changes in the equilibrium binding of the radioligand) of a saturating concentration of a competitive ligand, which will bind to the unoccupied receptors and prevent reassociation of the radioligand with the receptor, or by diluting the sample by at least 100 -fold to reduce the free concentration of radioligand by this factor (so that its concentration is far lower than its $K_{\mathrm{a}}$ and binding will subsequently be negligible).

5 At the appropriate time, terminate the reaction to separate bound from free radioligand and determine radioactivity as described in Protocol 1.2.

\section{Notes}

${ }^{a}$ As described in Protocol 1.2.

${ }^{b}$ As described in Protocol 1.2.

${ }^{c}$ For nonspecific binding, ensure that the competitive ligand is present in the assay for the entire incubation period with radioligand.

${ }^{d} \mathrm{Be}$ aware that low ligand concentrations will take longer to equilibrate.

\subsubsection{Kinetic radioligand binding assays in the presence of an allosteric modulator using isotopic dilution}

A competitive ligand cannot change the dissociation binding kinetics of an orthosteric ligand as the two cannot occupy the receptor at the same time. However, when an allosteric modulator binds to a receptor, it may alter the receptor conformation such that it forms a 'new' receptor species that has a new set of affinities for its orthosteric ligands. This is often reflected in alterations in the association and/or dissociation kinetics of the orthosteric ligand. Kinetic radioligand binding assays can, therefore, be used to reveal important information regarding the binding mechanism of a ligand and are a sensitive way to determine whether two ligands can bind to a receptor 


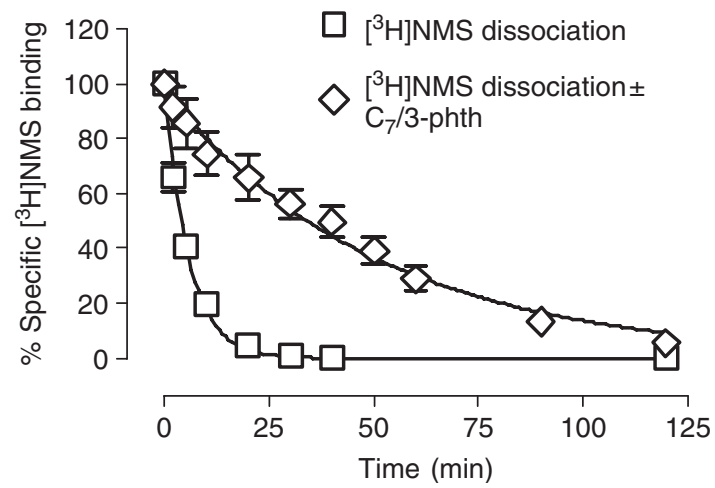

Figure 1.7 Dissociation of the radioligand, $\left[{ }^{3} \mathrm{H}\right] \mathrm{NMS}$, from the $M_{4}$ muscarinic ACh receptor in the absence and presence of the muscarinic receptor allosteric modulator, $C_{7} / 3$-phth. The radioligand was allowed to equilibrate with the receptor for $1 \mathrm{~h}$ at $37^{\circ} \mathrm{C}$ before its dissociation was observed by the addition of a high concentration ( $100 \times$ the $K_{\mathrm{a}}$ ) of atropine in the absence and presence of $C_{7} / 3$-phth and termination of the assay as described in Section 1.2.

simultaneously (Protocol 1.6). Determination of the dissociation rate of a ligand in the absence and presence of another is the simplest way to measure kinetic effects (see Figure 1.7). The radioligand is usually allowed to reach equilibrium binding and its association with the receptor is prevented, as described previously, in the absence or presence of a putative allosteric modulator (for example, see [20] for protocols).

\section{PROTOCOL 1.6 Measurement of Radioligand Dissociation Kinetics in the Presence of an Allosteric Modulator}

\section{Equipment and Reagents}

- Membrane preparation

- Binding buffer ${ }^{a}$

- $5 \mathrm{ml}$ polypropylene assay tubes (Techno-plas)

- Radioligand

- Allosteric modulator

- Competitive antagonist

- Wash buffer ${ }^{b}$

- Water bath

- Vacuum harvester (Brandel)

- Glass-fibre filter paper (Whatman)

- Liquid scintillation cocktail (PerkinElmer)

- Liquid scintillation counter (e.g. Packard Tri-Carb LS counter). 


\section{Method}

1 Dilute the receptor preparation in assay buffer to $10 \times$ the final desired assay concentration and dilute the radioligand in assay buffer to approximately $10 \times$ its $K_{\mathrm{a}}{ }^{c}$ Dilute both the competitive ligand and the allosteric modulator in assay buffer to $200 \times$ the final desired assay concentration. Further dilute the competitive ligand at a $1: 1$ ratio with either the allosteric modulator or with assay buffer so that each ligand is $100 \times$ concentrated.

2 Prepare two sets of tubes containing radioligand, so that radioligand dissociation can be measured in one set and radioligand dissociation in the presence of the allosteric modulator can be measured in the other set. Also prepare tubes containing radioligand in which a saturating concentration of a competitive ligand will be incubated with the receptor throughout the experiment to define nonspecific binding.

3 Stagger the addition of membrane to tubes containing the radioligand and incubate for sufficient time so as to reach equilibrium binding.

4 Stagger the addition of the competitive ligand with and without the putative allosteric modulator. The tube set-up outlined in Table 1.5 can be used for this assay, with the allosteric modulator-competitive ligand mix being added in the appropriate tubes in place of the competitive ligand alone.

5 At the appropriate time, separate bound from free radioligand and determine radioactivity as described in Protocol 1.2.

\section{Notes}

${ }^{a}$ As described in Protocol 1.2.

${ }^{b}$ As described in Protocol 1.2.

${ }^{c}$ Generally, to observe kinetic effects, higher concentrations of an allosteric modulator will be required than those required to observe cooperative effects in equilibrium binding assays; therefore, reducing receptor occupancy by the radioligand will increase the ability to detect alterations in the binding kinetics of the radioligand.

\section{References}

1. Barcroft, J. and Hill, A.V. (1910) The nature of oxyhæmoglobin, with a note on its molecular weight. J. Physiol., 39, 411-428.

2. Hill, A.V. (1910) The possible effects of the aggregation of the molecules of haemoglobin on its dissociation curves. Proc. Physiol. Soc., 40, iv-vii.

3. Gaddum, J.H. (1937) The quantitative effects of antagonistic drugs. J. Physiol., 89, 7P-9P. One of the original publications by Gaddum describing the concept of competitive antagonism.

4. Gaddum, J.H. (1943) Introductory address. Part I. Biological aspects: the antagonism of drugs. Trans. Faraday Soc., 39, 323-332. 
5. Cheng, Y. and Prusoff, W.H. (1973) Relationship between the inhibition constant $\left(K_{\mathrm{i}}\right)$ and the concentration of inhibitor which causes 50 per cent inhibition $\left(I_{50}\right)$ of an enzymatic reaction. Biochem. Pharmacol., 22, 3099-3108.

6. De Lean, A., Stadel, J.M. and Lefkowitz, R.J. (1980) A ternary complex model explains the agonist-specific binding properties of the adenylate cyclase-coupled beta-adrenergic receptor. J. Biol. Chem., 255, 7108-7117.

The original publication describing a ternary complex model for GPCR activation.

7. Samama, P., Cotecchia, S., Costa, T. and Lefkowitz, R.J. (1993) A mutation-induced activated state of the beta 2-adrenergic receptor. Extending the ternary complex model. J. Biol. Chem., 268, $4625-4636$.

The original publication describing an extended ternary complex model for GPCR activation.

8. May, L.T., Leach, K., Sexton, P.M. and Christopoulos, A. (2007) Allosteric modulation of G protein-coupled receptors. Annu. Rev. Pharmacol. Toxicol., 47, 1-51.

A good review covering the concepts of allosterism and the detection and quantification of allosteric effects.

9. Ehlert, F.J. (1988) Estimation of the affinities of allosteric ligands using radioligand binding and pharmacological null methods. Mol. Pharmacol., 33, 187-194.

The original publication describing an allosteric ternary complex model.

10. Christopoulos, A. and Kenakin, T. (2002) G protein-coupled receptor allosterism and complexing. Pharmacol. Rev., 54, 323-374.

11. Langmead, C.J. and Christopoulos, A. (2006) Allosteric agonists of 7TM receptors: expanding the pharmacological toolbox. Trends Pharmacol. Sci., 27, 475-481.

12. Horstman, D.A., Brandon, S., Wilson, A.L. et al. (1990) An aspartate conserved among G-protein receptors confers allosteric regulation of alpha 2 -adrenergic receptors by sodium. J. Biol. Chem., 265, 21590-21595.

13. Galvez, T., Urwyler, S., Prézeau, L. et al. (2000) $\mathrm{Ca}^{2+}$ requirement for high-affinity $\gamma$-aminobutyric acid (GABA) binding at GABAB receptors: involvement of serine 269 of the GABABR1 subunit. Mol. Pharmacol., 57, 419-426.

14. Lowry, O.H., Rosebrough, N.J., Farr, A.L. and Randall, R.J. (1951) Protein measurement with the folin phenol reagent. J. Biol. Chem., 193, 265-275.

15. Bradford, M.M. (1976) A rapid and sensitive method for the quantitation of microgram quantities of protein utilizing the principle of protein-dye binding. Anal. Biochem., 72, 248-254.

16. Motulsky, H. and Christopoulos, A. (2004) Fitting Models to Biological Data Using Linear and Nonlinear Regression. A Practical Guide to Curve Fitting, Oxford University Press, Oxford.

17. DeBlasi, A., O'Reilly, K. and Motulsky, H.J. (1989) Calculating receptor number from binding experiments using same compound as radioligand and competitor. Trends Pharmacol. Sci., 10, $227-229$.

18. Arunlakshana, O. and Schild, H.O. (1959) Some quantitative uses of drug antagonists. Br. J. Pharmacol. Chemother., 14, 48-58.

One of the original publications describing concepts of competitive and noncompetitive antagonism and the use of the 'Schild plot'. 
19. Avlani, V., May, L.T., Sexton, P.M. and Christopoulos, A. (2004) Application of a kinetic model to the apparently complex behavior of negative and positive allosteric modulators of muscarinic acetylcholine receptors. J. Pharmacol. Exp. Ther., 308, 1062-1072.

20. Lazareno, S. and Birdsall, N.J. (1995) Detection, quantitation, and verification of allosteric interactions of agents with labeled and unlabeled ligands at $\mathrm{G}$ protein-coupled receptors: interactions of strychnine and acetylcholine at muscarinic receptors. Mol. Pharmacol., 48, 362-378.

21. Motulsky, H.J. and Mahan, L.C. (1984) The kinetics of competitive radioligand binding predicted by the law of mass action. Mol. Pharmacol., 25, 1-9. 
